\title{
Kosakonia cowanii as the New Bacterial Pathogen Affecting Soybean (Glycine max Willd.)
}

\author{
Krzysztof Krawczyk • Natasza Borodynko-Filas
}

Accepted: 19 April 2020/Published online: 5 May 2020

(C) The Author(s) 2020

\begin{abstract}
Soybean (Glycine max Willd.) is one of the most economically important crops in the world, and it's importance continuously increasing. Routine screening of Polish soybean fields has revealed an outburst of a new disease of soybean plants, with symptoms resembling those described for the bacterial blight, caused by Pseudomonas syringae pv. glycinae, and bacterial pustule caused by Xanthomonas axonopodis pv. glycines. The symptoms were observed in the field, on the leaves of investigated plants. The goal of this paper was the identification and characterization of the causal agent of that disease. Our studies have excluded virus and fungi and pointed the bacteria as the disease causal agent. Identification based on biological (Biolog Gen III), and molecular methods (16S rDNA, and gyrB sequencing, PCR species-specific testing) revealed that the soy pathogenic bacteria is Kosakonia cowanii species. We believe that the presence of such pathogens in the environment pose a serious threat for the crops and is also a warning, that in the near future we may be faced a new type of bacterial pathogens: both epi- and endophytic, abundant in the natural environment, with huge
\end{abstract}

\footnotetext{
K. Krawczyk $(\bowtie)$

Department of Molecular Biology and Biotechnology, Institute of Plant Protection-National Research Institute, Władysława

Węgorka 20, 60-318 Poznań, Poland

e-mail: k.krawczyk222@gmail.com

N. Borodynko-Filas

Plant Disease Clinic and Bank of Plant Pathogens, Institute of

Plant Protection-National Research Institute, Władysława

Węgorka 20, 60-318 Poznań, Poland
}

metabolic potential, and ability of quick colonization of new ecological niches and hosts, e.g. opportunistic pathogens of plants or humans. What's important is that the plant-pathogenic and plant-epiphytic "environmental" strains of such species can be distinguished from each other only post factum, in the pathogenicity tests. They are indistinguishable or very hard to distinguish morphologically, biochemically or molecularly.

Keywords Kosakonia cowanii $\cdot$ Soybean · Plant pathogenic bacteria $\cdot$ First report

\section{Introduction}

The economic importance of soybean (Glycine max Willd.) is growing. The world's production is estimated as 306.5 million tonnes and the area harvested is 117.5 million hectares (http://www.fao.org/faostat/en/\#da ta/QC/visualize/). For the European Union, those numbers are 8.8 million tonnes and 4.5 million hectares, respectively. The soybean is becoming one of the most important sources of protein, and its nutritional properties are much appreciated. The availability of multiple varieties of soybean makes its production possible in all parts of Poland.

In the field conditions, soybean can be affected by many potential diseases factors like bacteria or fungi. The most recognizable bacterial diseases of soybean are bacterial blight caused by Pseudomonas syringae pv. glycinea, and bacterial pustule caused by Xanthomonas axonopodis (syn. campestris). Bacterial blight occurs 
usually early in the season. The yield loss is rarely observed but economic losses can be reported when soybeans are grown for seed. Bacterial pustule causes reduced size and quantity of seeds and can cause premature defoliation. The disease is most prevalent in the late growing season and occurs wherever the soybeans are cultivated (Giesler 2011a; Young 1997).

Soybean crops are often affected by numerous fungal diseases (Giesler 2011b, 2013; Giesler et al., 2012a, b; Liu et al. 2012; Roy et al. 2014). Most fungal diseases occur wherever the soybean is grown. The crop losses resulting from fungal infection are reported with various frequency, nevertheless if reported, they can do much harm to the crops (Liu et al. 2012). That is why the phytosanitary actions, preventing disease development are so important. One of such actions is routine monitoring of soybean crops in the Wielkopolska region of Poland, which revealed an outburst of a new disease of soybean plants. The observed symptoms were not characteristic and resembled both bacterial and fungal disease. The goal of this paper is the identification and characterization of the disease causal agent.

\section{Materials and Methods}

\section{Plant Material}

In the seasons 2016-2017 the monitoring of soybean fields (var. Sułtan and Aldana) originally targeted on screening for Cucumber mosaic virus (CMV) occurrence on various hosts, revealed the outburst of a new disease of soybean plants. The symptoms resembled both bacterial and fungal disease but they were not specific to any described soybean disease. The leaves of symptomatic soybean plants were collected in 20162017, in Dłoń, in Wielkopolska Region of Poland $\left(51^{\circ} 41^{\prime} 24.1^{\prime \prime} \mathrm{N} 17^{\circ} 04^{\prime} 01.4^{\prime \prime} \mathrm{E}\right)$. The plant material was sampled in the midseason, between June and July, from the two fields (20 ha each) of var. Sułtan and Aldana. From each field maximum three random samples of symptomatic plants of each variety were sampled, every season.

\section{Pathogen Isolation}

The symptomatic leaves were delivered to the laboratory, disinfected (10\% sodium hypochlorite for $1 \mathrm{~min}$, next in $70 \%$ ethanol for $1 \mathrm{~min}$ ), and thoroughly washed in sterile distilled water. The leaves tissue was homogenized in sterile physiological saline $(0,9 \% \mathrm{NaCl})$ and investigated four-way: (i) original lesions were investigated under a microscope for producing streaming from infected tissue - which would suggest bacteria presence (ii) using the electron microscopy to verify the presence of viruses, (iii) homogenate dilutions spread on the PDA (Potato Dextrose Agar) medium (Sigma Aldrich Ltd.) to verify the presence of fungal pathogens, and (iv) spread on the TSA (Tryptic Soy Agar) medium (Sigma Aldrich Ltd.) to grow colonies of the potential bacterial causal agent. The colonies were grown up to five days to consider the slow growth of Xanthomonas bacteria. Since the symptoms resembled those described for bacterial pathogens, a part of investigated leave tissue, after disinfection and before homogenization, was placed in a humid chamber to observe the potential bacterial ooze appearance. After incubation, each colony phenotype grown from the homogenate on the microbiological media used was transferred on the new plates and a series of reduction streaks was performed to obtain the pure culture of each morphotype, from now, the isolate. The culture purity of each obtained isolate was verified with gram staining, under the optical microscope, and based on colony morphology.

\section{Pathogen Identification}

The tested plant material was investigated under the electron microscopy for the presence of virus particles, and the inoculum from the original lesions was streaked on the PDA medium to observe a potential fungal pathogen growth. Also, the inoculum from the original lesions was investigated under a microscope, for detection of streaming from infected tissue, produced by most bacterial pathogens.

The bacterial isolates were identified using both biochemical and molecular methods. Biochemical identification was performed using the Biolog's Gen III system Biolog Gen III (BIOLOG Inc. Hayward, CA) according to the manufacturer instructions. The Biolog's database (v. 2.8.0) contains 1568 bacterial species comprising 258 plant pathogenic bacteria, including Xanthomonas axonopodis and Pseudomonas syringae. Molecular identification was based on the $16 \mathrm{~S}$ rDNA and gyrB gene partial sequence. The bacterial genomic DNA was isolated using a CTAB protocol (García-González et al. 2018). The water solution of obtained DNA was kept at $-20{ }^{\circ} \mathrm{C}$ for further experiments. The bacterial universal 
primers: 16SA1/16SA2 (Ishii et al. 2013) were used to multiply a partial $16 \mathrm{~S}$ rDNA gene sequence for identification purposes. Also, in the same manner, the $1480 \mathrm{~F} /$ 2242R primer pair (Bonasera et al. 2014) amplifying the partial gyrase B gene nucleotide sequence was used to confirm the 16S rRNA based identification results. A touch-down PCR protocol (TD-PCR) (Korbie and Mattick 2008) was used to obtain $\mathrm{a} \sim 1400$ and $1000 \mathrm{bp}$ long amplicons, respectively.

The expected size PCR products of general primers (16S rDNA and gryrB) were cleaned using Wizard SV Gel and PCR Clean-Up System (Promega, Madison, Wisconsin, USA), and sequenced (Genomed S.A., Warsaw, Poland). All obtained DNA sequences were verified and submitted to the GenBank database. To verify the results of identification of the Polish soy pathogenic isolates, their $16 \mathrm{~S} \mathrm{rDNA}$, and gyrB sequences were cross-referenced with related GenBank sequences, based on the BLAST analysis results, and employed in the phylogenetic analysis. Multiple sequence alignments were performed using ClustalW software, and a phylogenetic tree was constructed in Mega 6.0 software, using the neighbor-joining method with bootstrapping (1000 repeats). The tree was rooted with a Pectobacterium carotovorum 16S rDNA sequence (NR_025316.1), and gyrB (FJ652727.1). All Accession numbers and the names of the strains used in the analysis are listed on the computed dendrograms.

For additional confirmation of the general primers based identification (16S rDNA and gyrB), the speciesspecific primer pairs were used to potentially confirm or exclude the presence of soybean bacterial pathogens. For detection of the presence of P. syringae the D21/ D22 primer pair was used as described earlier (N. W. Schaad et al. 2001). For detection of $X$. axonopodis pv. glycinea, the heu2/heu4 primers were used (Changsik et al. 1999). Finally for detection of $P$. savastano $i$ a two primer pairs were used IAALF/IAALR, and PSS1/PSS2 (Mirik et al. 2011). The PCR products were electrophoretically separated and visualized under UV light, and results were described.

\section{Pathogenicity Test}

Each obtained bacterial isolate was tested in a pathogenicity test, in a greenhouse (temperature $20-25^{\circ} \mathrm{C}$, humidity $50-80 \%$ ), to confirm the Koch's postulates. For each bacterial isolate 5 soybean plants of Sultan variety, and 5 plants of Aldana variety was tested. The whole experiment was repeated twice.

Three methods of plant inoculation were used. The first method of inoculation involved atomizing bacterial suspension under high pressure, on both side of the leaves with a compressor sprayer, after wounding the leaves, by puncturing with a needle (EPPO Bulletin 2006). The second method involved rubbing the leaves with the bacterial suspension mixed with a small portion of carborundum used as a wounding factor. And, the third method involved inoculation of soybean plants with $1 \mathrm{ml}$ of bacterial suspension injected directly into leaves using a sterile syringe. For all inoculation techniques, a $10^{6}-10^{7} \mathrm{cfu} / \mathrm{ml}$ concentration of each isolate was used. Also, after inoculation, each plant was kept in a humid chamber for $48 \mathrm{~h}$, and then in the greenhouse, until the disease symptoms development. After symptoms development, the plants were subjected the reisolation to confirm Koch's postulates. The experiment negative control was sterile distilled water used instead of the bacterial suspension.

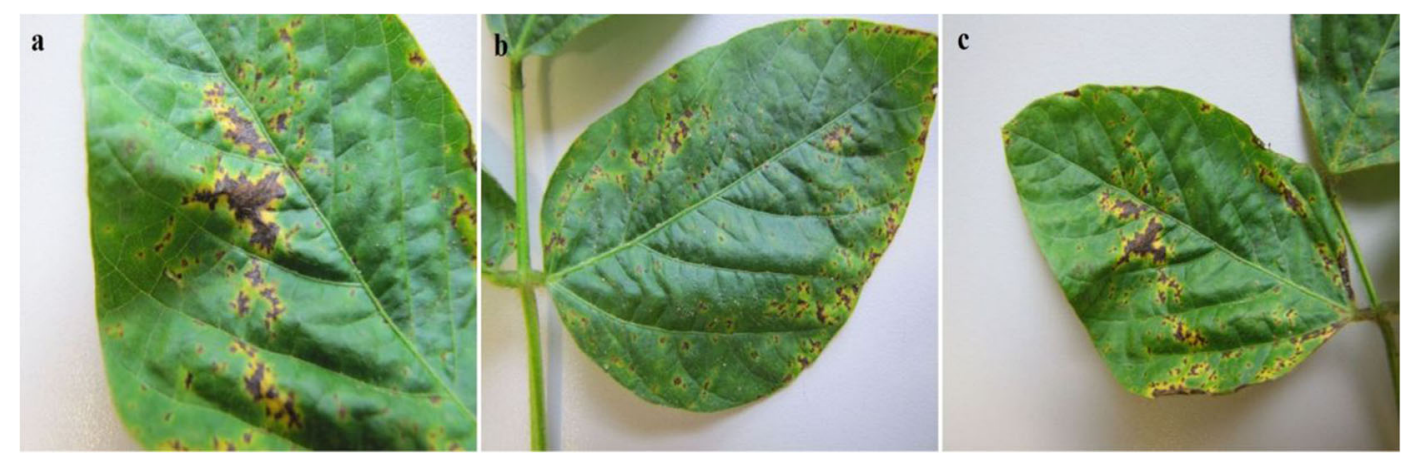

Fig. 1 The disease symptoms observed on the tested soybean plants $(\mathbf{a}, \mathbf{b}, \mathbf{c})$ 


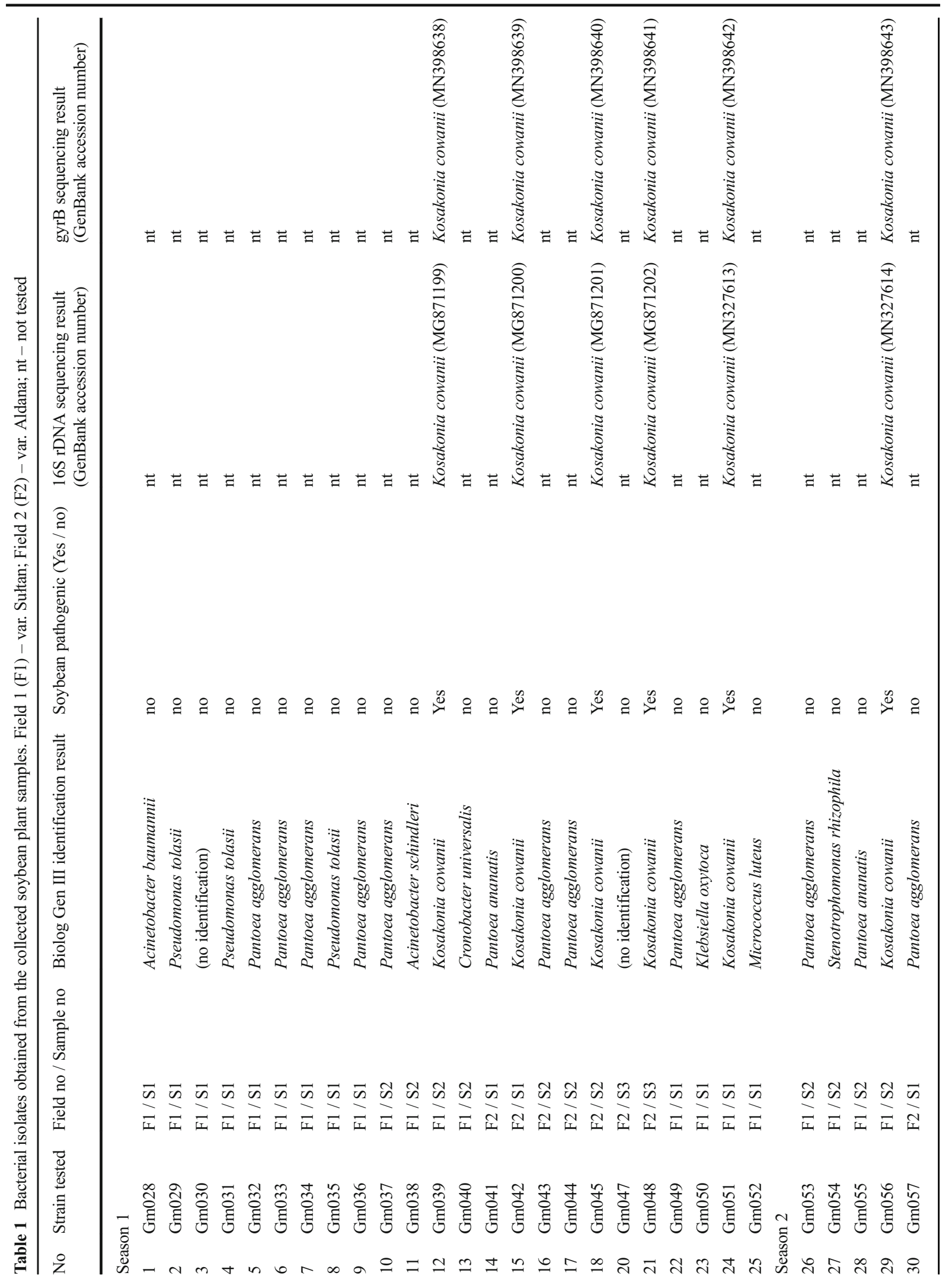


Results

The Disease Symptoms

The symptoms were observed during the two vegetation seasons (2016-2017) on the leaves of investigated plants. Out of the 40 ha (two fields of 20 ha each), approximately one-third of crop surface has exhibited the disease symptoms. The early disease phase involved tiny brown spots surrounded by a clear, yellow halo. After 5-7 days, the brown spots have turned into irregular, dark brown lesions with dark-brown centres. In the final disease stage, some lesions merge each other and turn into dark-brown, drying out necrosis (Fig. 1a-c). The symptoms have caused a significant crop reduction, due to reducing the photosynthetically active leave surface. The symptoms observed in the field (Fig. 1a-c) were similar to several described soybean diseases but were not characteristic for any of them. It somewhat resembled those described for the bacterial blight, caused by Pseudomonas syringae pv. glycinae, and bacterial pustule caused by Xanthomonas axonopodis $p v$. glycines, but also the sudden death syndrome of soybean caused by the Fusarium virguliforme (Roy et al. 2007), and brown spot caused by the fungus Septoria glycines (Giesler 2011b).

\section{Pathogen Identification}

In the tested plant material, no virus particles were observed under the electron microscopy and no fungal growth was observed on the PDA medium, hence both the viral and fungal causal agents of the observed disease symptoms were excluded. The investigation of inoculum from original lesions under a microscope showed the presence of streaming from an infected tissue, which is characteristic for most bacterial plant pathogens, moreover after incubation of the symptomatic leaves in the humid chamber $\left(48 \mathrm{~h}\right.$ at $\left.27^{\circ} \mathrm{C}\right)$, the bacterial ooze was observed. Hence further diagnostics was focused on bacteria.

In general, the 37 bacterial isolates were obtained from the diagnostic material. The pure cultures of all 37 isolates were identified biochemically using Biolog's Gen III system. The identified isolates belonged to ten bacterial species: Acinetobacter baumannii. (1 isolate), A. schindleri (1), Cronobacter universalis (1), Klebsiella oxytoca (1), Kosakonia cowanii (10), Micrococcus luteus (1), Pantoea agglomerans (12), 
P. ananatis (4), Pseudomonas tolaasii (3), Stenotrophomonas rhizophila (1) and 2 isolates with no reference in Biologs's database (v. 2.8.0) (Table 1).

In each sample tested the most abundant strain was $K$. cowanii. Also, all symptoms-causing isolates defined in the pathogenicity tests were identified as K. cowanii. They were identified molecularly using the $16 \mathrm{~S}$ rRNA, and gyrB genes sequencing, which confirmed initial Biolog's biochemical identification results (Table 1). Dendrograms of $16 \mathrm{~S}$ rDNA and gyrB sequences were generated using the neighbour-joining method and involved nucleotide sequences of each gene of $9 \mathrm{~K}$. cowanii original strains, $3 \mathrm{~K}$. cowanii reisolation strains (Gm0391, Gm0421, Gm0511), 4 sequences of each of most common soybean bacterial pathogens: $P$. savastano $i, P$. syringae, and $X$, axonopodis. The 1 sequence of $P$. carotovorum used as outgroup. Both dendrograms results confirmed the accuracy of the Polish strains identification and shows that the strains identified as $K$. cowanii, cluster together, as the most similar, with other GenBank references of this species, and not with the most common soybean bacterial pathogens mentioned (Figs. 2 and 3).

The pathogen identification results were additionally verified by using the published, species-specific, primer pairs for bacterial soybean pathogens: $P$. syringae, $P$. savastanoi and $X$. axonopodis pv. glycinea (Table 2). For all K. cowanii isolates tested, the results were following: as expected the $X$. axonopodis $\mathrm{pv}$. glycinea and $P$. savastanoi primers gave no PCR products. The $P$. syringae specific primers gave no proper size PCR product. The same result was obtained for the three $K$. cowanii isolates (Gm039-1, Gm042-1, Gm051-1) obtained after the reisolation (Table 2). Also, the identification of the isolates by $16 \mathrm{~S}$ rDNA

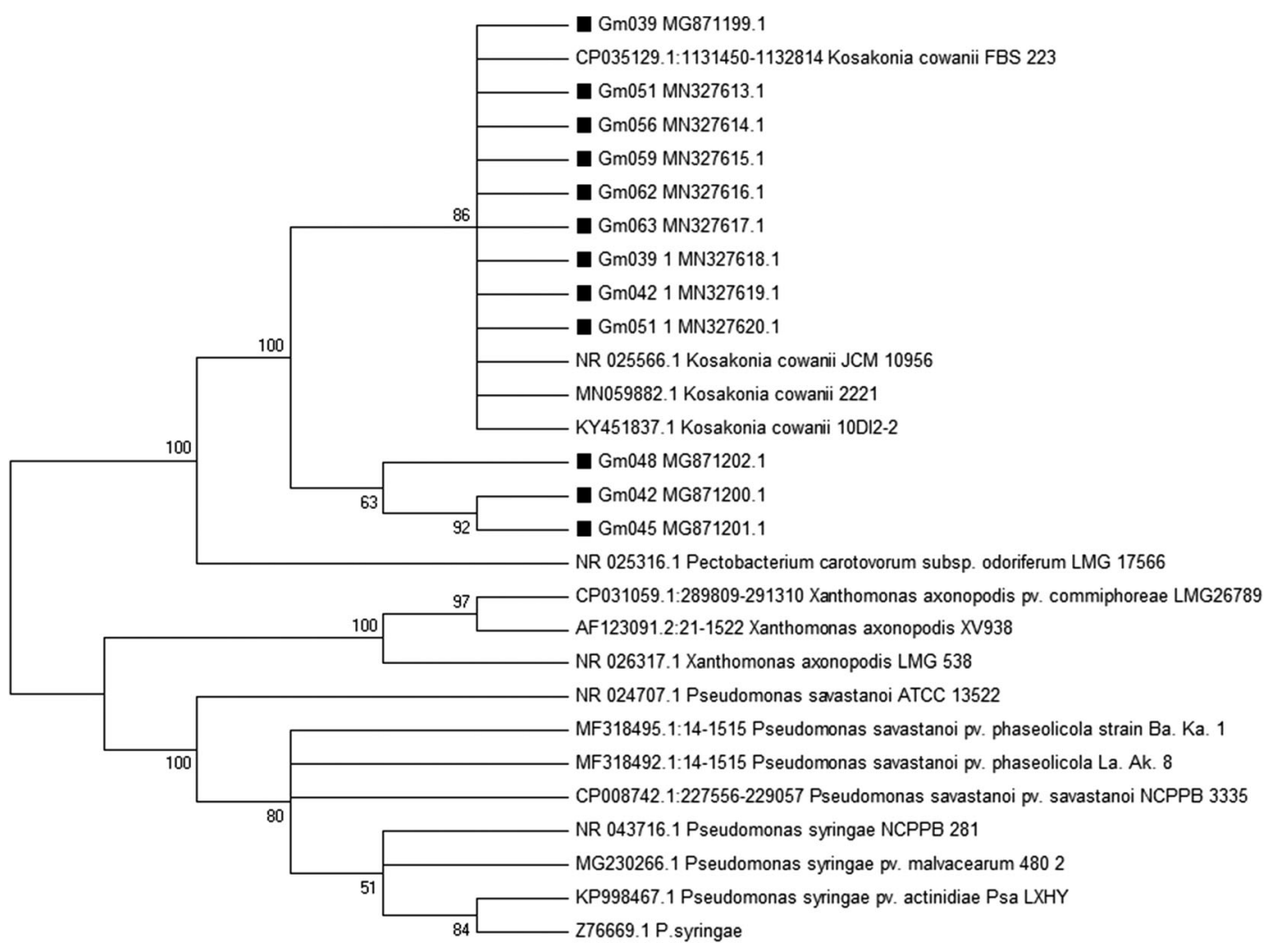

Fig. 2 The results of the neighbour-joining analysis of the 16S rRNA gene partial nucleotide sequences from the $K$. cowanii strains affecting the soybean and from the sequences of $16 \mathrm{~S}$ rRNA of the most common soybean bacterial pathogens like Pseudomonas syringae, P. savastanoi and Xanthomonas axonopodis. The Pectobacterium carotovorum sequence (NR_025316.1) was used as outgroup to root the tree. The
Polish $K$. cowanii isolates are marked with black squares. The sequences were analyzed using the BioEdit (v7.0.5.3) and Mega (v 6.0) software. The multiple sequence alignments and the phylogenetic analysis were performed using the ClustalW and the neighbour-joining algorithms implemented with BioEdit and Mega programs, respectively. Bootstrap values were based on 1000 pseudoreplicates for phylogenetic comparisons 


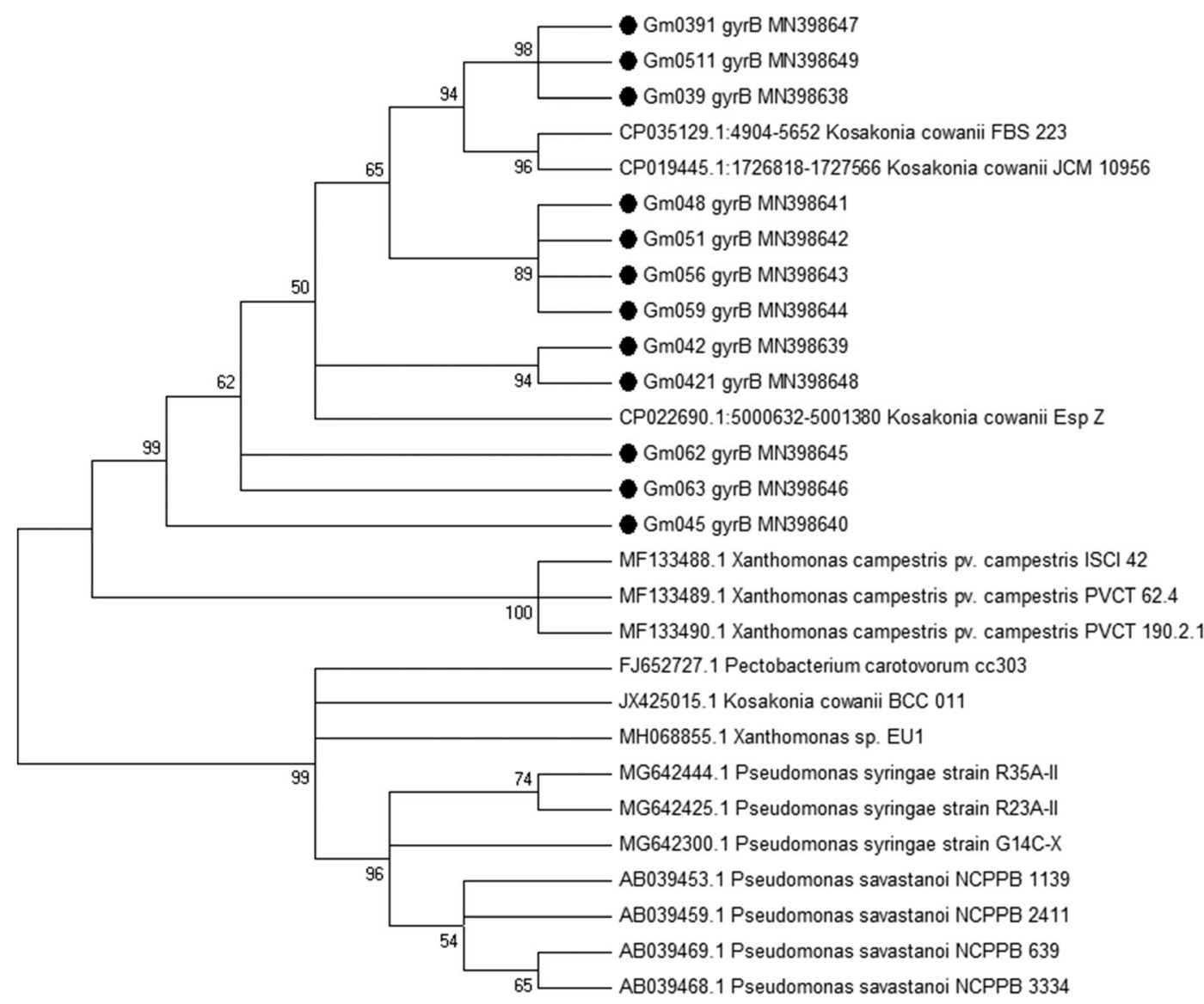

Fig. 3 The results of the neighbour-joining analysis of the gyrB gene partial nucleotide sequences from the $K$. cowanii strains affecting the soybean and from the sequences of gyrB gene of the most common soybean bacterial pathogens like Pseudomonas syringae, P. savastanoi and Xanthomonas axonopodis. The Pectobacterium carotovorum sequence (FJ652727.1) was used as outgroup to root the tree. The Polish $K$. cowanii isolates are

(MN327618, MN327619, MN327620) and gyrB (MN398647, MN398648, MN398649) sequencing marked with black circles. The sequences were analyzed using the BioEdit (v7.0.5.3) and Mega (v 6.0) software. The multiple sequence alignments and the phylogenetic analysis were performed using the ClustalW and the neighbour-joining algorithms implemented with BioEdit and Mega programs, respectively. Bootstrap values were based on 1000 pseudoreplicates for phylogenetic comparisons

confirmed the identity of the strains as $K$. cowanii (Figs. 2 and 3, respectively).

Table 2 The results of testing of the soybean pathogenic strains of $K$. cowanii with P. syringae, P. savastanoi and X. axonopodis pv. glycinea species-specific primers

\begin{tabular}{lllll}
\hline Primer pair & Target species & $\begin{array}{l}\text { Amplicon } \\
\text { size (bp) }\end{array}$ & Reference & $\begin{array}{l}\text { Strains tested: Gm039, Gm042, Gm045, } \\
\text { Gm048, Gm051, Gm056, Gm059, Gm062, } \\
\text { Gm063, GM039-1, Gm042-1, } \\
\text { and Gm051-1 } \\
\text { Species-specific primer verification result }\end{array}$ \\
\hline D21/D22 & P. syringae & 558 & (Norman W Schaad et al. 2001) & no proper size PCR product \\
heu2/heu4 & X. axonopodis pv. glycines & 860 & (Changsik et al. 1999) & no PCR product \\
IAALF/IAALR & P. savastanoi & 464 & (Mirik et al. 2011) & no PCR product \\
PSS1/PSS2 & P. savastanoi & 684 & (Mirik et al. 2011) & no PCR product \\
\hline
\end{tabular}



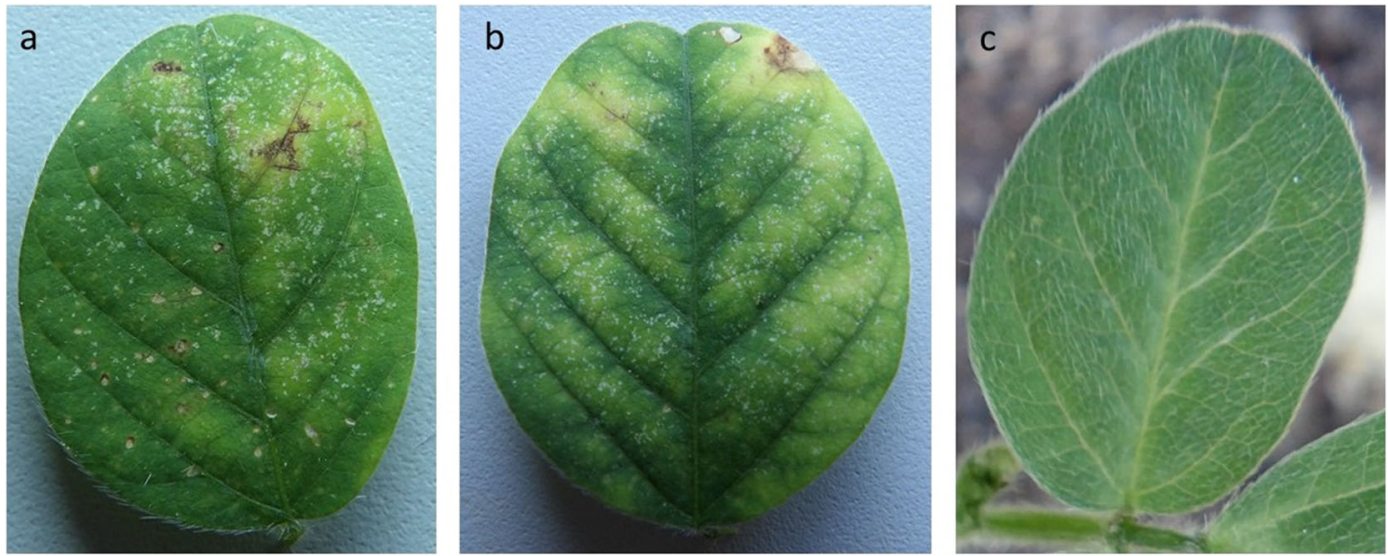

Fig. 4 Symptoms observed after spraying the bacterial suspension on the soybean leaves; $\mathrm{a}$ - var. Sultan; b - var. Aldana; $\mathrm{c}-$ negative control - leave sprayed with sterile water

\section{Pathogenicity Test}

After incubation in the humid chamber $\left(48 \mathrm{~h}\right.$ at $\left.27^{\circ} \mathrm{C}\right)$, the bacterial ooze was observed on the symptomatic leaves. In total, from both, tested symptomatic leaves and bacterial ooze samples, 37 bacterial isolates were obtained and tested in the greenhouse assay. After soy plants inoculation, the disease symptoms were observed for nine out of 37 tested isolates (Table 1). The symptoms were observed on both tested varieties Sultan and Aldana. In the greenhouse, after inoculation, for all methods used, the symptoms developed within 37 days. The obtained symptoms were referred to the negative control which was leaves treated with sterile distilled water. In case of the method involving spraying the bacterial suspension under pressure, on the leaves, the symptoms resembled the original ones, observed in the field (Fig. 4).

For the second method involving rubbing the leaves with the bacterial suspension mixed with a small portion of carborundum used as a wounding factor, the symptoms observed were lesions around the place of inoculation (Fig. 5).

For the third method involving the injection of bacterial suspension into the leaves, the symptoms observed were lesions around the place of inoculation (Fig. 6).

All results obtained in this paper suggest that $K$. cowanii is the causal agent of the new soybean bacterial disease. To our knowledge, this is the first report of $K$. cowanii affecting soybean plants in the world.

\section{Discussion}

According to the EPPO database all three soybean bacterial pathogens mentioned in the introduction: $X$. axonopodis pv. glycinea, $P$. syringae pv. glycinea and $P$. savastanoi pv. glycinea has been reported both in Poland and in Poland's neighbouring countries. $X$. axonopodis pv. glycinea was reported in France, Ukraine, Lithuania and Russia (https://gd.eppo.
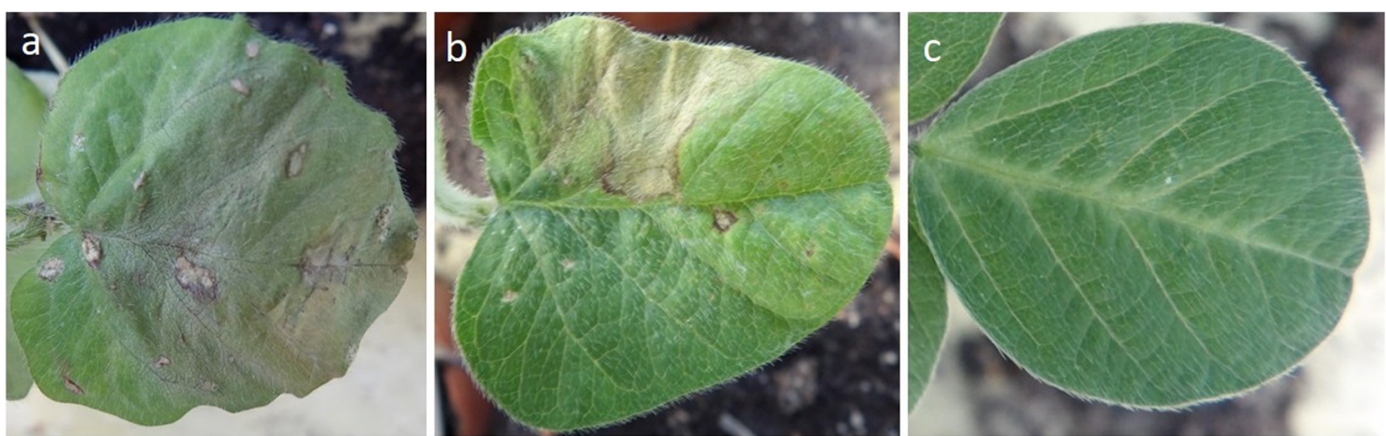

Fig. 5 Symptoms observed after rubbing the leaves with the bacterial suspension mixed with a small portion of carborundum used as a wounding factor; $\mathrm{a}$ - var. Sultan; b - var. Aldana; c - negative control - leave treated with sterile distilled water 
int/taxon/XANTGL/distribution). P. syringae pv. glycinea was reported in Czech Republic, France, Germany, Poland, and Russia (https://gd.eppo. int/taxon/PSDMGL/distribution). P. savastanoi $\mathrm{pv.}$ glycinea was reported in France, Germany, Poland, Russia, and Ukraine (https://gd.eppo. int/taxon/PSDMGL/distribution). There are also much earlier reports of soybean bacterial blight in Poland (Marcinkowska et al. 1982). Being aware of this fact and based on the initial test revealing the presence of the bacterial streaming under the microscope, and resemblance of the observed symptoms to those described for bacterial diseases, we performed bacteria focused diagnostics of the symptomatic soybean plants. We obtained 37 strains, and all of them were subjected to the pathogenicity tests, and biochemical identification using a biochemical method based on Biolog Gen III system with database v.2.8 containing the $P$. syringae, $P$. savastanoi, $X$. axonopodis and $K$. cowanii reference profiles. The positive result in the pathogenicity test was recorded only for the strains identified as $K$. cowanii (9 isolates). Next, we thoroughly confirmed the $K$. cowanii strains identity by performing a molecular identification based on sequencing of the partial 16S rRNA, and gyrB genes, and also excluded the presence of soybean pathogens using species-specific PCR primers. Obtained results were also verified against the GenBank nucleotide database, and the phylogenetic analysis was performed. All results have confirmed that $K$. cowanii is the causal agent of new bacterial disease of soybean plants. To our knowledge, this is the first report of $K$. cowanii affecting soybean plants in the world.

A $K$. cowanii exhibits the set of characteristic features. It is polyphagic, commonly present and abundant in many ecological niches, environmentally competitive, and with huge metabolic potential. The $K$. cowanii is common in the soil, in water and the sewage. Most of its strains are not phytopathogenic, however, this species has been reported as a pathogen of eucalyptus (Brady et al. 2009) and the woody plants (Furtado et al. 2012). Some strains of this species are also opportunistic human pathogens (Grimont and Grimont 2006; Mardaneh and Soltan-Dallal 2014; Peleg et al. 2008; Yang et al. 2018). This species ability to colonize so various ecological niches suggest that it has a versatile and easy adaptable metabolism, and can easily adapt to new conditions and host like e.g. soybean. The occurrence of $K$. cowanii (synonym Enterobacter cowanii) on the soybean plants is in congruence with general ecology of the genus Enterobacter which includes many metabolically diverse species (Grimont and Grimont 2006). For instance, Enterobacter cloaceae is an endophyte of papaya (Thomas et al. 2007), and Enterobacter gergoviae is an endophyte of maize (An et al. 2007).

We believe that the presence of this pathogen in the environment poses a serious threat for the crops and is also a warning, that in the near future we may be faced to a new type of bacterial pathogens affecting crops. This new type of pathogen isis the bacteria with the same properties as the K. cowanii like e.g. Pantoea ananatis, P. agglomerans, and E. cloaceae subsp. dissolvens. Those common properties are abundance in the natural environment, a huge metabolic potential, the ability of quick colonization of new ecological niches and hosts, e.g. opportunistic pathogens of plants or humans. What's important is that the plant-pathogenic and plant-epiphytic "environmental" strains of such species can be distinguished from each other only post factum, in the pathogenicity tests. They are indistinguishable or very hard to distinguish morphologically, biochemically or molecularly.

The P. ananatis and P. agglomerans were also detected in our soybean samples (Table 1), however, they did not cause the disease symptoms on the test plants in the greenhouse. Nevertheless, both those species are
Fig. 6 Symptoms observed after injecting the bacterial suspension into the soybean leaves; a - var. Sultan; b - var. Aldana

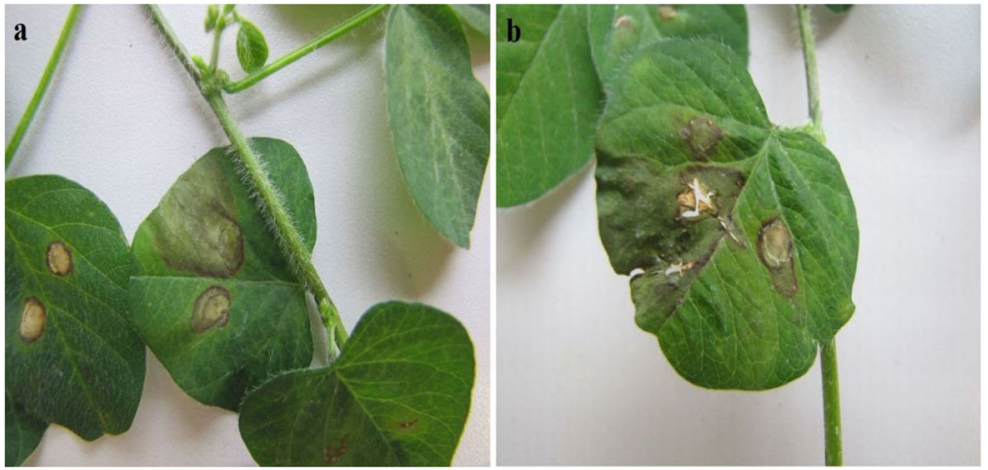


described as plant pathogens and plant epiphytes. The $P$. ananatis is associated, among others, with leaf spot disease of maize reported in South Africa (Goszczynska et al. 2007), Brazil (Paccola-Meirelles et al. 2001), and Mexico (Pérez-Y-Terrón et al. 2009). Its presence in soybean is in congruence with the earlier studies which describe $P$. ananatis as an unconventional plant pathogen, which when is not plant-associated can occupy diverse ecological niches and can be also plant endophyte, symbiont or finally pathogen (Coutinho and Venter 2009). Similarly with P. agglomerans which, is known from both its deleterious and beneficial effects on plants, animals and humans (Dutkiewicz et al. 2016a, 2016b). The third mentioned bacterial species E. cloaceae subsp. dissolvens was not detected in the tested soybean plants, however, it also fits this characteristic. Among others, it affects the chilli pepper seedlings (García-González et al. 2018). Some of its strains are epiphytic or endophytic and nonphytopathogenic, and some are plant pathogenic. It is abundant in the environment easily adaptable to different ecological niches. It's polyphagic and polyphagic and widespread (Grimont and Grimont 2006). Also what needs to be emphasized is that K. cowanii, P. ananatis, P. agglomerans, and E. cloaceae subsp. dissolvens, share another important, common feature: they are considered as opportunistic human pathogens (De Baere et al. 2004; Dutkiewicz et al. 2016b; Grimont and Grimont 2006; Rezzonico et al. 2009; Stock et al. 2001; Yang et al. 2018).

Currently, both plant-pathogenic and plant notpathogenic bacterial strains of the described species exist together in the natural environment and have the unlimited possibility to exchange each other's genetic material. We do not know the percentage of pathogenic and nonpathogenic strains in a population of each of those species. We do not know whether the pathogenic strains will or will not gain an advantage over the non-pathogenic strains and become a new threat for the crops, which is quite probable in today's climate warming conditions.

Acknowledgements This study was supported by project no. 2014/13/B/NZ9/02108 from National Science Centre of Poland. Compliance with ethical standards

Conflict of interest The authors declare that they have no conflict of interest.

Research involving human participants and/or animals Not applicable. The research involved no human participants or animals.
Informed consent The research involved no human participants, and no animals so that the statement on the welfare of animals is not required.

Open Access This article is licensed under a Creative Commons Attribution 4.0 International License, which permits use, sharing, adaptation, distribution and reproduction in any medium or format, as long as you give appropriate credit to the original author(s) and the source, provide a link to the Creative Commons licence, and indicate if changes were made. The images or other third party material in this article are included in the article's Creative Commons licence, unless indicated otherwise in a credit line to the material. If material is not included in the article's Creative Commons licence and your intended use is not permitted by statutory regulation or exceeds the permitted use, you will need to obtain permission directly from the copyright holder. To view a copy of this licence, visit http://creativecommons. org/licenses/by/4.0/.

\section{References}

An, Q., Dong, Y., Wang, W., Li, Y., \& Li, J. (2007). Constitutive expression of the nifA gene activates associative nitrogen fixation of Enterobacter gergoviae 57-7, an opportunistic endophytic diazotroph. Journal of Applied Microbiology, 103(3), 613620. https://doi.org/10.1111/j.1365-2672.2007.03289.x.

Bonasera, J. M., Asselin, J. E., \& Beer, S. V. (2014). Identification of bacteria pathogenic to or associated with onion (Allium сера) based on sequence differences in a portion of the conserved gyrase B gene. Journal of Microbiological Methods, 103, 138-143. https://doi.org/10.1016/j. mimet.2014.06.002.

Brady, C. L., Venter, S. N., Cleenwerck, I., Engelbeen, K., De Vos, P., Wingfield, M. J., et al. (2009). Isolation of Enterobacter cowanii from Eucalyptus showing symptoms of bacterial blight and dieback in Uruguay. Letters in Applied Microbiology, 49(4), 461-465. https://doi.org/10.1111 j.1472-765X.2009.02692.x.

Changsik, O., Sungii, H., \& Yong-Chul, C. (1999). Sensitive and Pathovar-specific detection of Xanthomonas campestris pv. glycines by DNA hybridization and polymerase chain reaction analysis. The Plant Pathology Journal, 15(1), 57-61.

Coutinho, T. A., \& Venter, S. N. (2009). Pantoea ananatis: An unconventional plant pathogen. Molecular Plant Pathology, 10(3), 325-335. https://doi.org/10.1111/j.1364-3703.2009.00542.x.

De Baere, T., Verhelst, R., Labit, C., Verschraegen, G., Wauters, G., Claeys, G., \& Vaneechoutte, M. (2004). Bacteremic infection with Pantoea ananatis. Journal of Clinical Microbiology, 42(9), 4393-4395. https://doi.org/10.1128 /JCM.42.9.4393-4395.2004.

Dutkiewicz, J., Mackiewicz, B., Lemieszek, M. K., Golec, M., \& Milanowski, J. (2016a). Pantoea agglomerans: A mysterious bacterium of evil and good. Part IV. Beneficial effects. Annals of Agricultural and Environmental Medicine, 23(2), 197-205. 
Dutkiewicz, J., Mackiewicz, B., Lemieszek, M. K., Golec, M., \& Milanowski, J. (2016b, June 2). Pantoea agglomerans: A mysterious bacterium of evil and good. Part III. Deleterious effects: Infections of humans, animals and plants. Annals of Agricultural and Environmental Medicine. https://doi. org/10.5604/12321966.1203878.

EPPO Bulletin. (2006). Xanthomonas fragariae. EPPO Bulletin, 36(1), 135-144. doi:https://doi.org/10.1111/j.13652338.2006.00926.x.

Furtado, G. Q., Guimarães, L. M. S., Lisboa, D. O., Cavalcante, G. P., Arriel, D. A. A., Alfenas, A. C., \& Oliveira, J. R. (2012). First report of Enterobacter cowanii causing a bacterial spot on Mabea fistulifera, a native forest species in Brazil. Plant Disease, 96(10), 1576.

García-González, T., Sáenz-Hidalgo, H. K., Silva-Rojas, H. V., Morales-Nieto, C., Vancheva, T., Koebnik, R., \& ÁvilaQuezada, G. D. (2018). Enterobacter cloacae, an emerging plant-pathogenic bacterium affecting chilli pepper seedlings. Plant Pathology Journal, 34(1), 1-10. https://doi. org/10.5423/PPJ.OA.06.2017.0128.

Giesler, L. J. (2011a). Bacterial diseases of soybean. The Board of Regents of the University of Nebraska on behalf of the University of Nebraska-Lincoln Extension, G2058, 1-2. http://extension.unl.edu/publications

Giesler, L. J. (2011b). Brown spot of soybean. The Board of Regents of the University of Nebraska on behalf of the University of Nebraska-Lincoln Extension, G2059, 1-2. $\mathrm{http}$ //extension.unl.edu/publications

Giesler, L. J. (2013). Frogeye leaf spot of soybean. The Board of Regents of the University of Nebraska on behalf of the University of Nebraska-Lincoln Extension, G2213, 1-2. $\mathrm{http} / / /$ extension.unl.edu/publications

Giesler, L. J., Harveson, R. M., Jackson-ziems, T. A., Korus, K. A., Liu, B., \& Wegulo, S. N. (2012a). Soybean disease profiles II stem and root rot diseases. The Board of Regents of the University of Nebraska on behalf of the University of Nebraska-Lincoln Extension, EC1904, 1-2.

Giesler, L. J., Harveson, R. M., Jackson-Ziems, T. A., Korus, K. A., Liu, B., \& Wegulo, S. N. (2012b). Corn foliar diseases. The Board of Regents of the University of Nebraska on behalf of the University of Nebraska-Lincoln Extension, EC1903, 1-2.

Goszczynska, T., Botha, W. J., Venter, S. N., \& Coutinho, T. A. (2007). Isolation and identification of the causal agent of brown stalk rot, a new disease of maize in South Africa. Plant Disease, 91(6), 711-718. https://doi.org/10.1094/PDIS-91-6-0711.

Grimont, F., \& Grimont, P. A. D. (2006). The genus Enterobacter. Prokaryotes, 6, 197-214. https://doi.org/10.1007/0-38730746-X_9.

Ishii, Y., Matsuura, Y., Kakizawa, S., Nikoh, N., \& Fukatsua, T. (2013). Diversity of bacterial endosymbionts associated with macrosteles leafhoppers vectoring phytopathogenic phytoplasmas. Applied and Environmental Microbiology, 79(16), 5013-5022. https://doi.org/10.1128/AEM.01527-13.

Korbie, D. J., \& Mattick, J. S. (2008). Touchdown PCR for increased specificity and sensitivity in PCR amplification. Nature Protocols, 3(9), 13-15. https://doi.org/10.1038 /nprot.2008.133.

Liu, B., Giesler, L. J., Jackson-Ziems, T. A., Wegulo, S. N., Harveson, R. M., Korus, K. A., \& Klein, R. N. (2012). Major Fusarium diseases on corn, wheat, and soybeans in
Nebraska. The Board of Regents of the University of Nebraska on behalf of the University of Nebraska-Lincoln Extension Resources, G2181, 1-4. http://extension.unl. edu/publications

Marcinkowska, J., Tomala-Bednarek, J. W., \& Schollenberger, M. (1982). Soybean diseases in Poland. Acta Agrobotanica, $35(2), 213-224$.

Mardaneh, J., \& Soltan-Dallal, M. M. (2014). Isolation and identification of Enterobacter cowanii from powdered infant formula in NICU and determination of antimicrobial susceptibility of isolates. Iranian Journal of Pediatrics, 24(3), 261266.

Mirik, M., Aysan, Y., \& Sahin, F. (2011). Characterization of Pseudomonas savastanoi pv. savastanoi strains isolated from several host plants in Turkey and report of fontanesia as a new host. Journal of Plant Pathology, 93(2), 263-270.

Paccola-Meirelles, F., Meirelles, M., \& Casela. (2001). Detection of a bacterium associated with a leaf spot disease of maize in Brazil. Journal of Phytopathology, 149(5), 275-279. https://doi.org/10.1046/j.1439-0434.2001.00614.x.

Peleg, A. Y., Seifert, H., \& Paterson, D. L. (2008). Acinetobacter baumannii: Emergence of a successful pathogen. Clinical Microbiology Reviews, 21(3), 538-582. https://doi. org/10.1128/CMR.00058-07.

Pérez-Y-Terrón, R., Villegas, M. C., Cuellar, A., Muñoz-Rojas, J., Castañeda-Lucio, M., Hernández-Lucas, I., et al. (2009). Detection of Pantoea ananatis, the causal agent of leaf spot disease of maize, in Mexico. Australasian Plant Disease Notes, 4(1), 96-99. https://doi.org/10.1071/DN09041.

Rezzonico, F., Smits, T. H., Montesinos, E., Frey, J. E., \& Duffy, B. (2009). Genotypic comparison of Pantoea agglomerans plant and clinical strains. BMC Microbiology, 9, 204. https://doi.org/10.1186/1471-2180-9-204.

Roy, K. W., Hershman, D. E., Rupe, J. C., \& Abney, T. S. (2007). Sudden death syndrome of soybean. Plant Disease, 81(10), 1100-1111. https://doi.org/10.1094/pdis.1997.81.10.1100.

Roy, K. W., Hershman, D. E., Rupe, J. C., \& Abney, T. S. (2014). Sudden death syndrome of soybean. The Board of Regents of the University of Nebraska on behalf of the University of Nebraska-Lincoln Extension, G2243, 1-2. doi:https://doi. org/10.1094/pdis.1997.81.10.1100.

Schaad, Norman W, Jones, J. B., Chun, W., \& others. (2001). Laboratory guide for the identification of plant pathogenic bacteria. American Phytopathological Society (APS Press).

Stock, I., Grüger, T., \& Wiedemann, B. (2001). Natural antibiotic susceptibility of strains of the Enterobacter cloacae complex. International Journal of Antimicrobial Agents, 18(6), 537545. https://doi.org/10.1016/S0924-8579(01)00463-0.

Thomas, P., Kumari, S., Swarna, G. K., \& Gowda, T. K. S. (2007). Papaya shoot tip associated endophytic bacteria isolated from in vitro cultures and host-endophyte interaction in vitro and in vivo. Canadian Journal of Microbiology, 53(3), 380-390. https://doi.org/10.1139/w06-141.

Yang, X. J., Wang, S., Cao, J. M., \& Hou, J. H. (2018). Complete genome sequence of human pathogen Kosakonia cowanii type strain 888-76T. Brazilian Journal of Microbiology, 49(1), 16-17. https://doi.org/10.1016/j.bjm.2017.03.010.

Young, X. B. (1997). Soybean bacterial blight and Brown spot.Pdf. Iowa State University Extension, Pm 1662, 1-2. 